TITLE:

\title{
ON TWO SPECIES OF DORIOPSIS (SYN. CTENODORIS) FROM JAPAN (NUDIBRANCHIA-DORIDIDAE)
}

$\operatorname{AUTHOR}(\mathrm{S})$ :

Baba, Kikutaro; Hamatani, Iwao

CITATION:

Baba, Kikutaro ...[et al]. ON TWO SPECIES OF DORIOPSIS (SYN. CTENODORIS) FROM JAPAN (NUDIBRANCHIA-DORIDIDAE). PUBLICATIONS OF THE SETO MARINE BIOLOGICAL LABORATORY 1961, 9(1): 63-65

\section{ISSUE DATE:}

1961-05-30

URL:

http://hdl.handle.net/2433/174662

RIGHT: 


\title{
ON TWO SPECIES OF DORIOPSIS (SYN. CTENODORIS) FROM JAPAN (NUDIBRANCHIA-DORIDIDAE) ${ }^{1)}$
}

\author{
KiKUTÅô BABA and Iwao hAMATANI \\ Biological Laboratory, Osaka Gakugei University; \\ Sennan Senior High School, Sennan City, Osaka Pref.
}

With 1 Text-figure

The genus Doriopsis Pease, 1860 (Syn. Ctenodoris Eliot, 1907; Guyonia RISBEC, 1928) is especially marked by having simply pinnate gills in a transverse row, and a crescentic gill cavity. The known members of the genus appear to differ from one another mainly in colour; they may tentatively be arranged as follows :

Yellow forms :

Doriopsis gramulosa PEASE, 1860. Hawaii.

Doriopsis scabra PEASE, 1871. Tahiti.

Doriopsis aurantiaca (ELIOT, 1913). Japan.

Doriopsis flava (RIsBec, 1928). New Caledonia; New South Wales; ? Maldive.

Doriopsis flabellifera (Cheeseman, 1881). New Zealand.

Dark green form:

Doriopsis viridis PEASE, 1861. Tahiti; New Caledonia.

Blue form:

Doriopsis pecten (Collingwood, 1881). Keelung; New Caledonia; New South Wales.

It is questionable whether each of the yellow forms stands specifically valid. As to the dark green form and the blue one, they are assumed by RISBEC (1928, 1953) to be varieties of a single species (see also Allan, 1947).

\section{Doriopsis aurantiaca (ELIOT, 1913)}

Kiiro-kushiera-umiushi

Doris (Ctenodoris) aurantiaca ElioT, 1913, pp. 5-7, pl. 1, fig. 1.-Sagami Bay (Misaki).

Ctenodoris aurantiaca BABA, 1937, pp. 301-302, text-fig. 5.-Amakusa (Tomioka); BABA, 1949, pp. 63,150 , pl. 24, fig. 87, text-fig. 76.-Sagami Bay (Hayama).

1) Contributions from the Seto Marine Biological Laboratory, No. 361.

Publ. Seto Mar. Biol. Lab., IX (1), 1961. (Article 5) 
Total length up to $35 \mathrm{~mm}$. Back covered everywhere with obtuse granules of various sizes. Gills 11-20. Dorsum always of a citron yellow, the granules indistinctly dotted with chocolate, under side of body paler than above. For the radula, see BABA, 1937, 1949. Animal may sometimes be found from above the yellow sponge colony (BABA, 1937). Spawns obtained,in September, 1955, from Osaka Bay, citron yellow, about $41 / 2$ convolutions, measuring ca. $35 \mathrm{~mm}$ across the whole mass in surface view; the egg-capsules containing $1(-2)$ eggs (diameter of the egg-cell ca. 100\%) in each.

Dist.: Sagami Bay (Misaki; Hayama); Kii ; Osaka Bay; Amakusa; Toyama Bay. Common.

Doriopsis aurantiaca is very closely allied to D. granulosa in the yellow colour of the body, but in the latter species the dorsal granules are said to be green; for the present, the species aurantiaca is separated from granulosa.
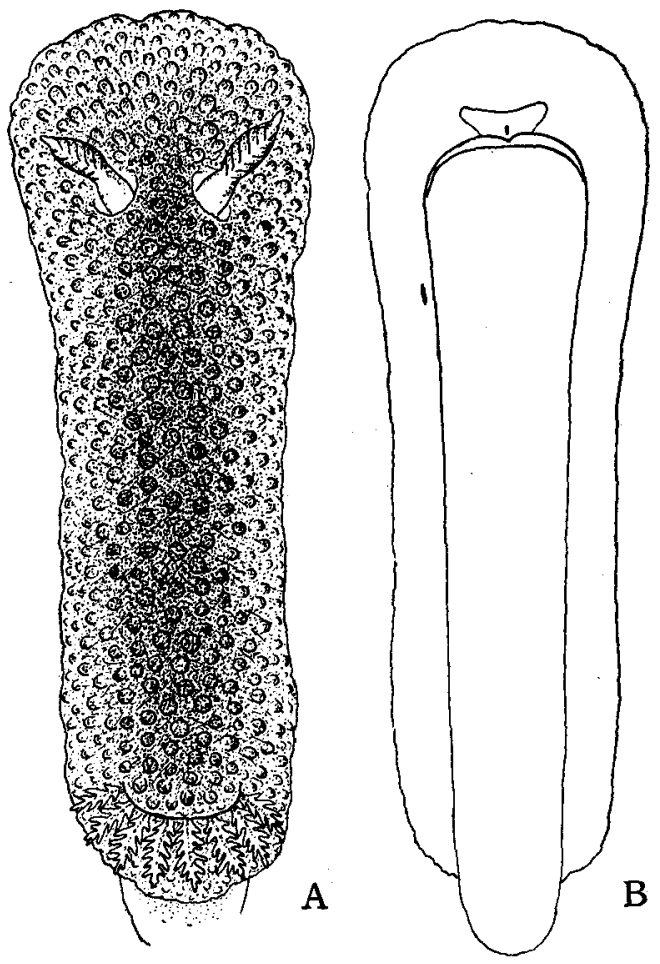

Fig. 1. Doriopsis viridis.

A. Animal from above; B. Animal from below. Hatakejima, Kii, July 23, 1960, length $7 \mathrm{~mm}$. 


\section{Doriopsis viridis PEASE, 1861 \\ Ao-kushiera-umiushi}

(Fig. 1)

Doriopsis viridis PeASE, 1861, pp. 244-245.-Tahiti ; PeAse, 1871, p. 301, pl. 19, fig. 1. Doris pecten Collingwood, 1881, p. 126, pl. 9, figs. 1-5.-Keelung.

Guyonia viridis RisBEC, 1928, pp. 105-106, pl. 3, fig. 4 (variété bleue).--New Caledonia.

Doriopsis viridis RISBEC, 1953, pp. 44-45 (variété bleue).-New Caledonia; ALLAN, 1947, p. 449; pl. 42, fig. 5.-New South Wales.

Total length 7-10 mm. Back covered as usual with spiculate, obtuse granules. Gills 8-9. General body-colour above indigo blue, somewhat deeper on the top of the granules. Rhinophores and gills also indigo blue. Under side of body paler than above, sole whitish. Mouth part without labial plates. Radula formula $30 \times 30.0 .30$, all of the lateral teeth simply hamate. Animal found living on a blue sponge colony.

Loc.: Hatakejima, Tanabe Bay, Kii (July 1960, 3 sps., coll. by Dr. Isamu YAMAZI).

\section{REFERENCES}

AllaN, J. 1947. Nudibranchia from the Clarence River Heads, north coast, New South Wales. Rec. Austr. Mus., vol. 21, no. 8. (Doriopsis flava, D. viridis)

BABA, K. 1937. Opisthobranchia of Japan (II). Journ. Dept. Agric. Kyushu Imp. Univ., vol. 5, no. 7 .

1949. Opisthobranchia of Sagami Bay. Iwanami Shoten, Tokyo.

COLLINGwood, C. 1881 . On some new species of nudibranchiate Mollusca from the eastern seas. Trans. Linn. Soc. London, Zool., vol. 2, pt. 2.

Eliot, C. 1913. Japanese nudibranchs. Journ. Coll. Sci. Imp. Univ. Tokyo, vol. 35, art. 1.

PEASE, W.H. 1860. Descriptions of new species of Mollusca from the Sandwich Islands. Proc. Zool. Soc. London.

Soc. London.

1861. Descriptions of new species of Mollusca from the Pacific Islands. Proc. Zool.

1871. Descriptions of nudibranchiate Mollusca, inhabiting Polynesia. Amer. Journ. Conch., vol. 6, pt. 4 .

Pruvot-Fol, A. 1947. Les opisthobranches de W. Harper PeAse. Révision. Journ. Conchyliol., vol. 87, no. 3. (Doriopsis)

RISBEC, J. 1928. Contribution a l'étude des nudibranches Néo-Calédoniens. Faune colon. Franç., tom. 2. (Guyonia flava, G. viridis)

1953. Mollusques nudibranches de la Nouvelle-Calédonie. Faune l'union Franç., vol. 15. (Doriopsis pecten $=D$. flava, D. viridis)

SUTER, H. 1913. Manual of the New Zealand Mollusca. (Ctenodoris flabellifera) 